\title{
GEOLOGY AND DISTRIBUTION OF RADIOELEMENTS AS WELL AS ENVIRONMENTAL IMPACT AT ABU MARW YOUNGER GRANITES, SOUTH EASTERN DESERT, EGYPT
}

\author{
El Afandy A. H. and El Shayib G. B.
}

Nuclear Mterials Aurhority, Cairo, Egypt.

\begin{abstract}
This work discusses the geologic setting of Abu Marwarea, and the distribution of the natural radionuclides and assess the radiological hazard resulting from the granites in the area. The environmental background levels of natural radiation, human exposure and dose rates as well as possible environmental impacts of radiation were investigated. The field investigation of the different rock units, with references to their mode of occurrence, mutual relationships, petrography and regional structure resulted that the area is covered by Late Proterozoic igneous and metamorphic rocks. These rocks are nonconformably overlain by Cretaceous Nubian sandstone in the western and northern parts of the area and they arranged from the oldest to the youngest rocks by Metagabbros, Metavolcanics, Older granites (tonalities and granodiorites) and Younger granites (monzogranites, syenogranites and Alkali-feldspar granites).

The younger granitic rocks at Abu Marw area have low uranium and thorium contents, where the average contents of uranium are $1.14 \mathrm{ppm}, 5.7 \mathrm{ppm}$ and $2.1 \mathrm{ppm}$ and thorium are $15.2 \mathrm{ppm}, 22.5 \mathrm{ppm}$ and $13.8 \mathrm{ppm}$ for monzogranites, syenogranites and alkali feldspar granites. The excess values of uranium and thorium contents in syenogranites are due to the high contents of uranium and thorium bearing minerals in these rocks.

The environmental impacts of the monzogranires, syenogranites and alkali feldspar granites at Abu Marw area are studied. The radium equivalent activity (Raeq), gamma activity index (I $\gamma$ ), alpha activity index (I $\alpha)$, external hazard index (Hex), internal hazard index (Hin), external absorbed dose rate in outdoor $\left(\mathrm{D}_{\text {out }}\right)$ and indoor $\left(\mathrm{D}_{\text {in }}\right)$, annual effective dose $(\mathrm{AEDE})$, annual gondal dose equivalent (AGDE) and excess lifetime cancar risk (ELCR) are calculated. The studies concluded that all the environmental impacts dose rates values in the younger granitic rocks (monzogranites, syenogranites and alkali feldspar granites) rocks are lower than the publicpermissible values in these rocks and they are within the safety range for the public and workers. So, these rocks are safety for the building and ornamental materials.
\end{abstract}

Keywords: Abu Marw, radionuclides, radiological hazard, environmental impacts

\section{INTRODUCTION}

Granitoids constitute an important rock group that covers vast areas of the Arabian-Nubian shield. In Egypt, granitoids (cover about $35,00 \mathrm{Km}^{2}$ ) constitutingabout $35 \%$ of the basement rocks.

The younger granites are considered as oneof the most favorable host rocks for U-mineralizationin the world especially the peraluminous two-mica granites (Cuney et al., 1984; Poty et al., 1986; Friedrich et al., 1989). In general, the granites are rich in incompatible elements ( $\mathrm{Rb}, \mathrm{Nb}, \mathrm{Sn}, \mathrm{Th}$, and U) (Rameshbabu, 1999; Pal et al., 2007). Natural radioactivity is associated mainly with primordial radionuclides including the elements belong to the $238 \mathrm{U}, 232 \mathrm{Th}$ and $40 \mathrm{~K}$ series. The terrestrial background radiation is related to the type of rocks. The higher concentrations of uranium, thorium and potassium are associated with phosphate, calcrete and granite rocks (Nada, 2003; Nagdya, 2003; Abbadyetal., 2005; Harb, et al., 2008; El Aassy, et al.,2012; Hamidalddin, 2012,Walley El-Dine, et al., 2012,Sroor, et al., 2012, Abdel Halim, 2016., Moghazy, 2016 and El Afandyetal., 2018).

When a geological formation containing ${ }^{238} \mathrm{U}$ and ${ }^{232} \mathrm{Th}$ has not been disturbed (closed system) for more than a million years, the members of the individual decay series will have the same activity $\left(\mathrm{Bq} \mathrm{kg}^{-1}\right)$ 


\section{El Afandy A. H. and El Shayib G. B.}

which is known as secular equilibrium. However, when the geological formation is not closed to radionuclide migration, ${ }^{226} \mathrm{Ra}$ can migrate and be deposited somewhere outside the formation then secular equilibrium will not exist and the growth of ${ }^{226} \mathrm{Ra}$ by radioactive decay of its ancestors will not occur and ${ }^{226} \mathrm{Ra}$ is said to be unsupported. The geochemical mobility of natural radionuclides means that some environmental impacts and health effects may be caused if the exposure and dose rates of radiation exceed the permissible levels. Therefore, assessment of radiation doses from natural sources is of great importance where these sources are the largest contributor to the external dose of the world population, (UNSCEAR, 2000).

This work discusses the geologic setting of Abu Marw area and the distribution of the natural radionuclides and assesses the radiological hazard resulting from the monzogranites, syenogranites and alkali feldspar granites in the studied area using $\mathrm{NaI}$ (Tl) $\gamma$-ray spectrometers. The environmental background levels of natural radiation, human exposure and dose rates as well as possible environmental impacts of radiation were investigated.

\section{Geologic Setting}

The Abu Marw area is mainly covered by Late Proterozoic igneous and metamorphic rocks. These basement rocks are nonconformably overlained by Cretaceous Nubian sandstone in the western and northern parts of the study area.

The topographic features of Abu Marw area are mainly controlled by the different rock types, structures and erosional processes. The highest topographic feature in the area is G. Hadayib, which rises to $712 \mathrm{~m}$ above sea level. Also, high hilly countries mainly of granitic rocks are represented by G. Abu Marw, G. Um Arka. The metavolcanics and tonalites terrains exhibit low relief.

The study area is dissected by several drainage lines and their tributaries. The northern portion is dissected by Wadi Abu Marw, the eastern part by Wadi Hadayib and Wadi Um Arkawhile the south western part by Um Ashera (Fig.2.1). From the field geological investigation of the different rock units, with references to their mode of occurrence, mutual relationships, petrographical study and regional structure, the investigated area was covered by metamorphic and igneous rocks arranged from the oldest to the youngest into: metagabbros, metavolcanics, tonalities, granodiorites, monzogranites, syenogranites and Alkali-feldspar granites, (Fig.1).

Fig.1: Geological map of Abu Marw area, South Eastern Desert, Egypt after El-Afandy, 1994

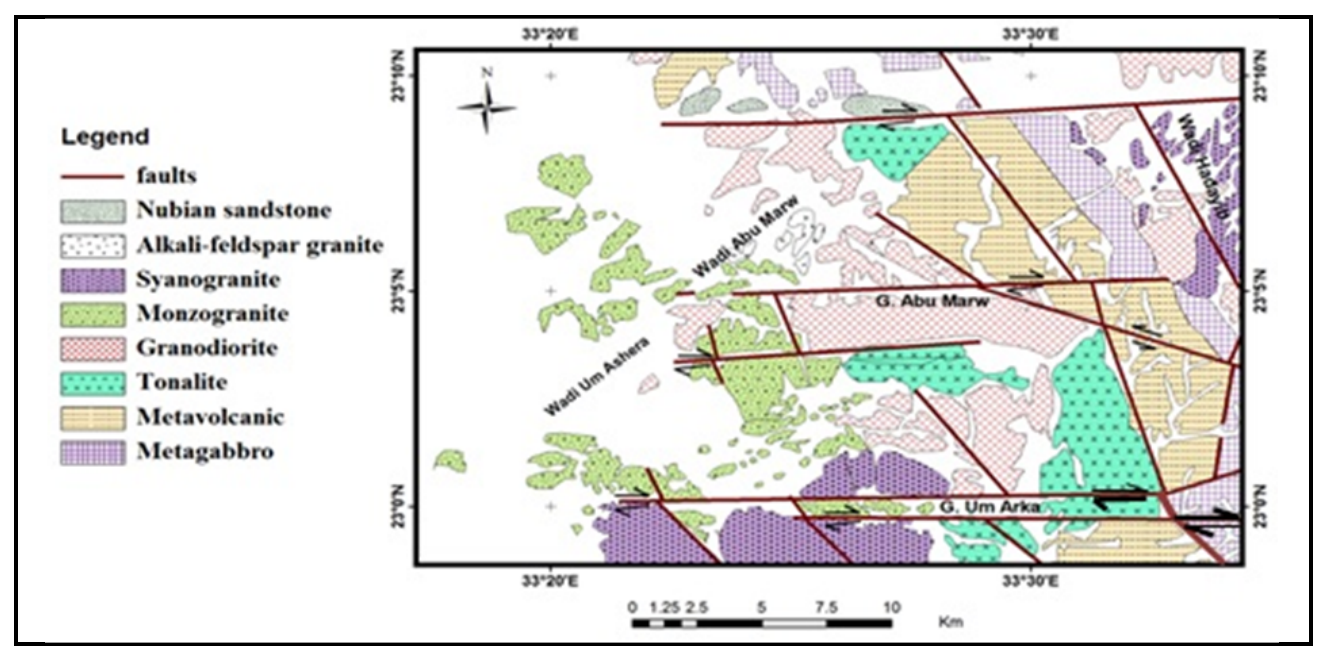

\section{Metagabbros}

The metagabbros constitute a narrow belt exposed along the eastern and southern parts of the studied area (Fig.1). In the northeastern part of the studied area, the metagabbros have an N-S trend east of WadiHadayib, and then it changes to NW direction. Also several isolated masses are observed partly covered by eolian sands in the central part of the studied area. In general, the metagabbros belt present adjacent and parallel to the metavolcanics belt. The contacts between metagabbros and the metavolcanics 


\section{Geology and distribution of radioelements}

are structurally contact, but the contacts between the metagabbros and the granitoid rocks are sharp contacts. The metagabbros are distinctly layered at the bottom of the masses grading upwards into coarse grained rocks which intern gradually change into fine grained rocks towards the top.

\section{Metavolcanics}

These rocks cover most of the eastern parts of the studied area. These rocks form low relief mountain ridges. The metavolcanic rocks are intruded by the tonalite and granodiorite rocks exposed to the west. The metavolcanics are sometimes capped by Nubian sandstones. The contact between the metagabbros and the metavolcanics are structural contact, but between the metavolcanics and the granitic rocks are intrusive contacts. These rocks are dissected by many faults striking ENE, E-W and NW directions.

Generally, the metavolcanics are fine to very fine grained rocks and display brown, green and/or grey colors. They are mainly basic to intermediate in composition, but acidic varieties are also present. The metabasalts together with metaandesites are dominating in the northern part of metavolcanic belt. These rocks are characterized by the presence of pillow structure towards the top especially in the northern part of the metabasalts. The metadacites together with the metarhyodacites are dominating in the southern part of the metavolcanics belt.

\section{Granitoid Rocks}

The granitoid rocks in the studied area constitute batholithic size bodies which invaded the metavolcanic rocks exposed in the eastern part of the mapped area. The granitoid rocks are partly covered by the Nubian sandstone especially at the western and northwestern parts of the mapped area. Field relations and geological observations revealed that thestudied granites are composed mainly of older and younger granites. The older granites are composed of tonalities and granodiorites, while the younger granites are composed of monzogranites, syenogranites and alkali-feldspar granites.

\section{The older granites}

\section{Tonalites}

The tonalite rocks form peripheral phase of the batholiths and exposed as curvilinear ridges along the northeastern and eastern part of batholith. They are typically foliated containing screens of the metamorphosed and foliated country rocks indicating forceful mode of intrusion characteristic of orogenic belt near active plate boundaries. The contacts between the tonalites and the surrounding metavolcanics, granodiorites, syenogranites and alkali-feldspar granites are sharp contacts. The tonalites are invaded by quartz feldspar porpherite dykes and some of them intersect each other (Fig.2).

\section{Granodiorites}

The granodiorite rocks form low relief hillocks occupying the eastern central part of the batholith due to the rapid weathering of these coarse grained rocks. These rocks are oriented in ENE-N-S and NW directions (Fig. 1). These rocks are fractured to lare exfoliated spheroidal boulders. They contain many dioritic xenoliths especially near the contacts with the tonalites. The contacts between the granodiorites and the surrounding rocks are sharp contacts. The granodiorites are partially covered by Nubian sandstones especially in the northwestern part of the mapped area. These rocks are invaded in the central part of the studied area by a nearly paralled dykes swarm trending E-W and extending for about $12 \mathrm{Km}$, these dykes are mostly of quartz feldspar porphery type ranging in thickness from 3-10m (Fig. 2).

\section{The younger granites}

\section{Monzogranites}

These rocks encountered in the central part of the granitic batholith. They surround the tonalites and granodiorites. These rocks are coarse grained and porphyritic. They are cut by NNW, NW, E-W and ENE faults. The contact between the monzogranites and the surrounding tonalites, granodiorites and syenogranites are intrusive and structural contacts. They form a continuous curve linear mountain range 


\section{El Afandy A. H. and El Shayib G. B.}

trending E-W and scattered group of circular or oval shaped hills in the northwestern part of the mapped area. These rocks are invaded by dykes and veins.

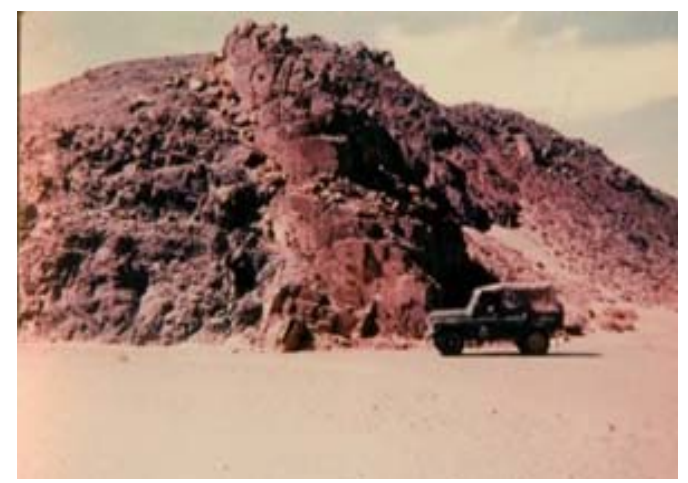

Fig. 2: Photograph showing two intersect quartz feldspar porphyritic dykes invaded in tonalites at Abu Marw area,

\section{Syenogranites}

They constitute the southern part of the mapped area (Fig. 1). They cutted by Wadi Um Arka and Wadi Um Ashera. These rocks cutted by NW and E-W faults. These rocks form a continuous mountain trending E-W and a scattered group of oval shape in the southwestern part of the mapped area. These rocks are fractured and invaded by many dykes ranging in composition from microgranites, basalts as well as pegmatite and quartz veins. The contact between these rocks and the surrounding rocks are sharp contacts.

\section{Alkali-feldspar granites}

These rocks occupy a limited area in the central part of the mapped area (Fig. 1). The rocks are pink to red in color, equigranular and scarce in mafic minerals. They have curvilinear isolated masses. The alkalifeldspar granites are low to moderate elevated mountains cutted by Wadi Abu Marw. They occupied an area of about $9 \mathrm{~km}^{2}$. The contacts between these rocks and the surrounding older rocks are sharp contacts.

\section{Petrography of the Younger Granites}

\section{Monzogranites}

These rocks are hybidiomorphic with myrmekitic texture. The monzogranite rocks are generally light pink, medium to coarse grain in size. Microscopically, they are composed essentially from quartz, Microcline perthite, microcline, plagioclase, biotite with minor amount of hornblende, whereas sphene and allanite are found as accessory minerals. Quartz (37.5\%) is present as subhedral to anhedral crystals with fine to medium in size and ranges in diameter from $0.6-2.4 \mathrm{~mm}$.It shows wavy extinction. It sometimes corroded the feldspar crystals and replaces their edges. Some parts in the cores exhibit poiklitic texture. Microcline (31.2\%) represented as subhedral medium to coarse grained crystals. Some microcline crystals are partially altered to sericite. Also, some crystals exhibit intergrowth with quartz forming graphic texture. Microcline perthiteof string type range from subhedral to anhedral crystals and vary in size grained. These crystals are corroded by quartz and sometimes altered to sericite. Plagioclase (29.2\%) crystals are of oligoclase composition, form anhedral to subhedral crystals, medium to coarse grain have lamellar twinning which have selective alteration and sometimes showing percline twinning. Normal zoning with sausuritization occur in the core of crystal. Some of plagioclase has inclusion of microcline crystal in core. Biotite $2.78 \%$ ) forms subhedralbrown flakes, pleochroic from yellow to dark brown colors. It presents between plagioclase and quartz, sometimes biotite altered to muscovite. The apatite and sphene crystals are present as inclusion in biotite crystals. Hornblende $(0.58 \%)$ forms anhedral green crystals, pleochroic from pale to dark green, it presents in quartz.

The accessory minerals (1.8\%) are composed mainly of Sphenehas sphenoidal shape, euhedral in form, surrounded with quartz and sometimes with biotite. Zircon presents as euhedral prismatic crystals included in biotite and sometimes in the boundaries between biotite and plagioclase. Allanite occurs asmonoclinic prismatic zoned crystal of allanite associated with zircon and biotite. 


\section{Geology and distribution of radioelements}

\section{Syenogranites}

These rocks are coarse grained and pink in colour. They are essentially composed of K-feldspar, quartz, plagioclase and biotite, whereas the accessory minerals are sphene, zircon, apatite, muscovite and iron oxides, while epidote and chlorite are secondary minerals. Potash feldspar (38.96\%) is present as orthoclase and microcline perthite. It occurs as subhedral to anhedral elongate crystals. The microcline perthites are of patch, flame and string types. The orthoclase crystals have Simple twinning. The microcline perthite crystals are corroded by plagioclase crystals and mantled by quartz, indicating that the quartz have been crystallized after perthite. The potash feldspar crystals enclose plagioclase blebs that are scallered throughout the crystals. In some cases, the contact between the potash feldspar crystals shows reaction rims mostly filled with quartz and albite crystals. Sometimes, microcline perthite altered to sericite. Quartz (41.51\%) is present as coarse grained anhedral crystals. It corrodes plagioclase, biotite and potash feldspar crystals. It occasionally contains inclusions of sphene, zircon, and opaque crystals. They have undulose extinction. Sometimes, quartz crystals have skeletal shape. Plagioclase $(15.62 \%)$ is of oligoclase composition. It occurs as anhedral to subhedralcrystals. They are frequently corrodes biotite and corroded by quartz and potash feldspar. The plagioclase crystals show lamellar and Carlsbad-albite twinning and is commonly zoned and cracked due to low strain. Biotite $(2.51 \%)$ occurs as individual flakes or as clusters of irregular flakes which fill the interstitial spaces between the other crystals or included in the potash feldspar and quartz. The biotite crystals have inclusions of apatite and zircon, which is commonly surrounded with pleochroic haloes. It displays strong pleocrhism and sometimes altered to green chlorite with liberation of iron oxides especially along its cleavage planes.

The accessory and opaque minerals (1.46\%) are composed maily of Zircon present as euhedral prismatic crystals and commonly occurs as inclusions in biotite and quartz and sometimes associates apatite. Radioactivity caused metamictization (pleochroic hellos).Some of them are fresh and include opaque minerals and surrounded by quartz, microcline and perthite. Partial metamictization present in samples. Sphene occurs as elongate euhedral crystals of brown colour and high relief. It is also occurs as clusters of irregular minute crystals enclosed in biotite and potash feldspar crystals. Apatite occurs as colorless prismatic crystals (rod like texture).It is included in biotite with sphene. Iron oxides occur as subhedral opaque grains distributed throughout the rock or as irregular granules enclosed in biotite. Monazite presents aseuhedral crystal associated with plagioclase. Muscovite is very rare, but if present occurs as small irregular flakes or as fine aggregates developed by the alteration of the biotite. Epidote exits as discrete crystals and granular aggregates. It is formed by the alteration of feldspars and biotite. Chlorite occurs as small flakes of green colour formed after biotite.

\section{Alkali-feldspar granites}

These rocks are medium grained with pink to red colour and display hybidiomorphicequigranular texture. They are mainly composed of potash feldspar, quartz with subordinate plagioclase crystals and biotite as essential minerals. Muscovite, zircon, monazite and iron oxides are accessories, while chlorite and sericite are secondary minerals. The mafic minerals are scarce giving rise to the leucogranite type. Potash feldspar $(62.5 \%)$ crystals are represented by orthoclase and microcline perthites whereas the latter is dominant. They occur as large crystals corroded by quartz. These perthites form string, rod and flame with patchy and net-like types. Alteration is widespread represented by sericite. The perthite crystals enclose small plagioclase, biotite, apatite and iron oxides inclusions. Tiny laths of albite develop along the grain boundaries. Quartz (29.3\%) occurs as large subhedral crystals as well as fine grained crystals occupying the interstitial spaces between the feldspars. They have undulose extinction). Many inclusions are observed including plagioclase, potash feldspar laths, zircon and opaque minerals. In some samples, it develops as graphic intergrowth texture with perthite. Plagioclase $(2.8 \%)$ is mainly of oligoclase composition and presents as euhedral to subhedralcrystals. They are slightly altered to sausurite and corroded by potash feldspar. Twinning according to albite law is common. Some crystals are zoned with intense alteration of the inner zones. Biotite $(3.7 \%)$ is less common and occurs as subhedral prismatic flakes with pleochroic from brown to dark brown. It is extensively altered to chlorite and rimmed by iron oxides. Biotite encloses minute crystals of sphene, zircon and iron oxides. 


\section{El Afandy A. H. and El Shayib G. B.}

The accessory and opaque minerals (1.9\%) are composed mainly of zircon, monazite, apatite, allanite, muscovite, garnet and iron oxides. Zircon is found as the most abundant accessory minerals in the granite. It occurs as euhedral prismatic crystals. They are commonly associated with biotite and iron oxides and occasionally exhibit color zoning as well as metamictization. Monazite is scarce, but if present is often metamict and occurs as minute euhedral pleochroic crystals with pale yellow color. It is found associated with zircon and iron oxides or enclosed in perthite crystals. Apatite is scarce, and occurs as colorless short prismatic crystals enclosed in biotite and associated with iron oxides. Allanite is rare and occurs as fine subhedral crystals. Muscovite occurs as irregular flakes in the interstitial spaces between the quartz and feldspars. It is found as the alteration of feldspar and biotite. Iron oxides occur as subhedral grains distributed throughout the rock or included in biotite crystals. Garnet is euhedral, hexagonal in shape and included in biotite.

\section{Analytical Techniques}

Twenty one representative samples frommonzogranites, syenogranite and the alkali-feldspar granite were measured in the radiometric laboratory in Nuclear Materials Authority for their U, Th, Ra and K contents using a high efficiency multichannel analyzer of -ray spectrometer $\mathrm{NaI}(\mathrm{Tl})$. The radiometric measurement for these radionuclides was carried out through four energy regions.

Since uranium and thorium are not $\gamma$-emitters, they were measured indirectly through the $\gamma$-ray photons emitted from their daughters, Th-234 (81-108 keV) for U-238, Pb-212 (221-273 keV) for Th-232 and radiumwas measured from the gamma-ray photon emitted by Pb-214 (327-390 keV) whereas potassium was measured directly from the gamma-ray photon emitted by K-40 (1319-1471 keV).Consequently, they are expressed as equivalent uranium (eU), equivalent thorium (eTh) and equivalent Radium (eRa). The chosen energy regions for $\mathrm{U}, \mathrm{Th}, \mathrm{Ra}$ and $\mathrm{K}$ were determined from the indicated energy lines of the spectra generated by means of laboratory uranium, thorium, radium and potassium reference standard samples provided by the IAEA (Matolin, 1991). The samples were prepared for measurement according to procedures described by (Matolin, 1991; Hamby and Tynybekov, 2000; and Al-Jundi, 2002).

Values of eU, eTh and eRa, in ppm, as well as $\mathrm{K}$, in \%, were converted to activity concentration, $\mathrm{Bq}$ kg-1, using the conversion factors given by Polish Central Laboratory for Radiological Protection (Malczewski et al., 2004). These data were used for calculation of some radiological parameters to estimate the environmental impacts of the radionuclides aswould be shown later.

\section{Distribution of U, Th and K\% in the Studied Younger Granites}

The uranium contents in monzogranites range from 1.8 to $2.6 \mathrm{ppm}$ with an average $2.14 \mathrm{ppm}$, while the Th contents range from 13.6 to $16.5 \mathrm{ppm}$ with an average $15 \mathrm{ppm}$. Th/U ratios range from 5.5 to $8.3 \mathrm{ppm}$ with an average $7.2 \mathrm{ppm}$. In the syenogranites, the $U$ contents range from 6 to $12 \mathrm{ppm}$ with anaverage 7.9 $\mathrm{ppm}$, while the Th contents range from 17.7 to $34.6 \mathrm{ppm}$ with an average $22.5 \mathrm{ppm}$. Th/U ratios range from 3.1 to 4.9 with an average 4.1. The uranium contents in alkali-feldspar granite range from 1.4to 2.7 ppm with an average 2.1, while Th contents range from 9.9 to $23.1 \mathrm{ppm}$ with an average of $13.8 \mathrm{ppm}$. $\mathrm{Th} / \mathrm{U}$ ratios range from 4 to $9.2 \mathrm{ppm}$ with an average 6.6 as shown in Table (1).

\section{Geochemistry of $U$ and $T h$ in the Studied Granites}

The geochemical behavior of $U$ and Thin the monzogranites, syenogranites and alkali feldspar granites in the studied area is examined by plotting of $\mathrm{U}-\mathrm{Th}, \mathrm{U}-\mathrm{Th} / \mathrm{U}$ ratios, Th-U/Th ratios and U-Rbas shown in Figs. (3-6) and their radioactivity concentration average were correlated to the corresponding worldwide means (Fig. 7).

The variation diagram between the $\mathrm{U}$ and $\mathrm{Th}$ contents within the studied granitic rocks are shown in (Fig. 3). The figure shows an increasing trend and $U$ contents increase with increasing Th content. This means that the $U$ and Th contents are magnetically and their contents encountered in refractory minerals as sphene and metamictized zircon. 
Table 1: eU, eTh, eRa and $\mathrm{K}$ contents besides $\mathrm{eTh} / \mathrm{eU}$ and eU/Ra ratios of the studied rocks

\begin{tabular}{|c|c|c|c|c|c|c|c|c|c|c|}
\hline Rock Type & $\mathrm{U}(\mathbf{B q} / \mathbf{K g})$ & $\operatorname{Th}(\mathrm{Bq} / \mathrm{Kg})$ & $\mathbf{K}(\mathbf{B q} / \mathbf{K g})$ & eU(ppm) & eR(ppm) & eTh(ppm) & K\% & eTh/eU & eTh/K & (eU-eTh)/3.5 \\
\hline \multirow{6}{*}{$\begin{array}{l}\text { Alkali } \\
\text { Feldspar }\end{array}$} & 33.35 & 43.8 & 1615.1 & 2.7 & 9 & 10.8 & 5.16 & 4 & 2.1 & -0.39 \\
\hline & 28.4 & 54.4 & 1690.2 & 2.3 & 8 & 13.4 & 5.4 & 5.8 & 2.5 & -1.5 \\
\hline & 17.3 & 40.2 & 1677.7 & 1.4 & 6 & 9.9 & 5.36 & 7.1 & 1.8 & -1.43 \\
\hline & 30.9 & 93.8 & 1740.3 & 2.5 & 9 & 23.1 & 5.56 & 9.2 & 4.2 & -4.1 \\
\hline & 21 & 48.3 & 1646.4 & 1.78 & 8 & 11.9 & 5.26 & 7 & 2.3 & -1.7 \\
\hline & 27.1 & 56.1 & 1683.9 & 2.2 & 10 & 13.82 & 5.38 & 6.3 & 2.6 & -1.7 \\
\hline Average & 26.3 & 56.1 & 1675.6 & 2.1 & 8.3 & 13.82 & 5.35 & 6.6 & 2.6 & -1.8 \\
\hline \multirow{9}{*}{ Synogranite } & 76.6 & 92.2 & 1424.2 & 6.2 & 8 & 22.7 & 4.55 & 3.7 & 5 & -0.29 \\
\hline & 100 & 100.7 & 1536.8 & 8.1 & 11 & 24.8 & 4.91 & 3.1 & 5.1 & 1 \\
\hline & 118.6 & 140.5 & 1511.8 & 9.6 & 12 & 34.6 & 4.83 & 3.6 & 7.2 & -0.29 \\
\hline & 54.3 & 75.1 & 1602.6 & 4.4 & 6 & 18.5 & 5.12 & 4.2 & 3.6 & -0.89 \\
\hline & 56.8 & 87.696 & 1743.4 & 4.6 & 7 & 21.6 & 5.57 & 4.7 & 3.9 & -1.6 \\
\hline & 45.7 & 71.9 & 1452.3 & 3.7 & 6 & 17.7 & 4.64 & 4.8 & 3.8 & -1.4 \\
\hline & 51.9 & 84 & 1596.3 & 4.2 & 7 & 20.7 & 5.1 & 4.9 & 4.1 & -1.7 \\
\hline & 55.6 & 77.5 & 1518 & 4.5 & 6 & 19.1 & 4.85 & 4.2 & 3.9 & -0.96 \\
\hline & 69.2 & 91.6 & 1646.4 & 5.6 & 8 & 22.56 & 5.26 & 4 & 4.3 & -0.85 \\
\hline Average & 69.8 & 91.2 & 1559.1 & 5.7 & 7.9 & 22.5 & 4.98 & 4.1 & 4.5 & -0.77 \\
\hline \multirow{6}{*}{ Monzogranite } & 24.7 & 62.5 & 1205.1 & 2 & 5 & 15.4 & 3.85 & 7.7 & 4 & -2.4 \\
\hline & 22.2 & 55.2 & 1129.9 & 1.8 & 4 & 13.6 & 3.61 & 7.6 & 3.8 & -2.1 \\
\hline & 24.7 & 67 & 1011 & 2 & 6 & 16.5 & 3.23 & 8.3 & 5.1 & -2.7 \\
\hline & 28.4 & 66.2 & 1320.9 & 2.3 & 6 & 16.3 & 4.22 & 7.1 & 3.9 & -2.4 \\
\hline & 32.1 & 58.5 & 1173.8 & 2.6 & 5 & 14.4 & 3.75 & 5.5 & 3.8 & -1.5 \\
\hline & 26.4 & 61.1 & 1255.3 & 2.14 & 5 & 15 & 4.01 & 7 & 3.8 & -2.2 \\
\hline Average & 26.43 & 61.7 & 1182.6 & 2.14 & 5.2 & 15.2 & 3.8 & 7.2 & 4.1 & -2.2 \\
\hline
\end{tabular}


El Afandy A. H. and El Shayib G. B.
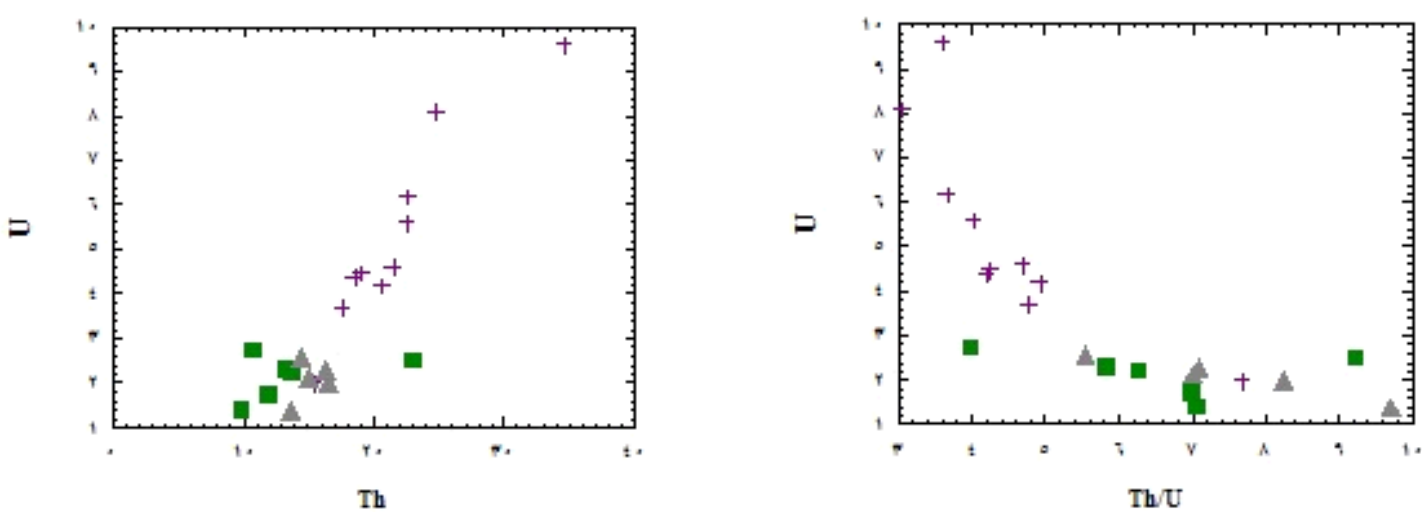

$\Delta$ Monzogranite + Syenogranite - Alkali feldspar granite

Fig. 3: Variation diagrams Th versus $U$ of the studied granitoid rocks.

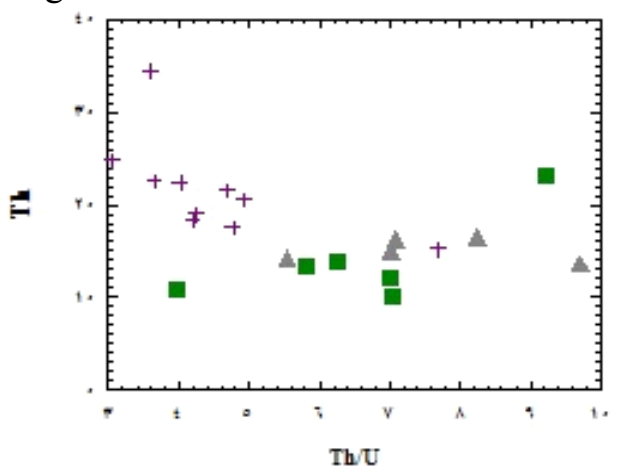

Fig. 5: Variation diagrams $\mathrm{Th} / \mathrm{U}$ versus $\mathrm{Th}$ of the studied granitoid rocks.
Fig. 4: Variation diagrams $\mathrm{Th} / \mathrm{U}$ versus $\mathrm{U}$ of the studied granitoid rocks.

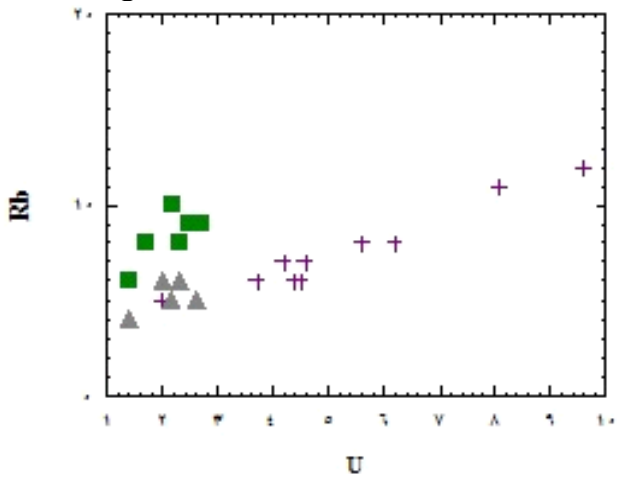

Fig. 6: Variation diagrams $\mathrm{U}$ versus $\mathrm{Rb}$ of the studied granitoid rocks.
Fg. 7: Radionuclides average concentration of different rocks at study area.

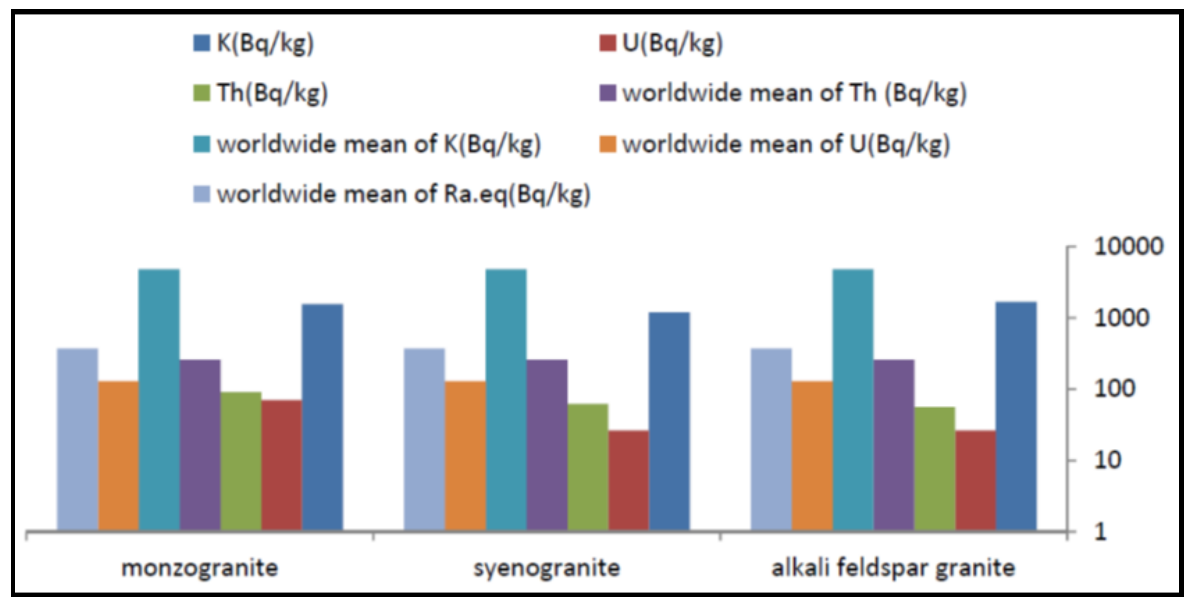

$\mathrm{U}$ against $\mathrm{Th} / \mathrm{U}$ is shown in (Fig. 4). The figure indicates that all the granitoid samples form a decreasing trend. This might indicate that the granitoid rocks form a co-magmatic series.

Figure (5) shows the variations of Th contents against $\mathrm{Th} / \mathrm{U}$ ratios within the granitoid rock series. The samples values increase in Th values with decreasing in $\mathrm{Th} / \mathrm{U}$ ratios.

$\mathrm{U}$ behaves incompatibly in silicate melts accompanied by elements such as $\mathrm{Rb}$. The variation diagram of $\mathrm{Rb}$ against $\mathrm{U}$ within the granitoid rock series are shown in Fig. (6). This figure show positive correlation with $\mathrm{U}$ contents.

\section{Evaluation of radiological hazard effects}

Values of eU and eTh in ppm, as well as $\mathrm{K}$, in \%, were converted to activity concentration, Bq/ $\mathrm{kg}$, using the conversion factors given by International Atomic Energy Agency, (IAEA, 1979, 1989 and 1996) and by Polish Central Laboratory for Radiological Protection (Rumyantsev, 1967, Malczewski 


\section{Geology and distribution of radioelements}

et al., 2004; El Galy et al., 2008). The specific parent activity of a sample containing $1 \mathrm{ppm}$, by weight, of $\mathrm{U}$ is $12.35 \mathrm{~Bq} / \mathrm{kg}$, $1 \mathrm{ppm}$ of Ra is $11.1 \mathrm{~Bq} / \mathrm{kg}$, and $1 \mathrm{ppm}$ of Th is $4.06 \mathrm{~Bq} / \mathrm{kg}$, and $1 \%$ of ${ }^{40} \mathrm{~K}$ is $313 \mathrm{~Bq} / \mathrm{kg}$. Therefore it can be easy to estimate the effects of this radiation through the calculation of the following parameters.

\section{Radium equivalent activity, $R \mathbf{a}_{\text {eq }}$}

The radium equivalent activity $\mathrm{Ra}_{\mathrm{eq}}$ is a weighted sum of activities of the ${ }^{238} \mathrm{U},{ }^{232} \mathrm{Th}$ and ${ }^{40} \mathrm{~K}$ radionuclides based on the assumption that $370 \mathrm{~Bq} / \mathrm{kg}$ of ${ }^{238} \mathrm{U}, 259 \mathrm{~Bq} / \mathrm{kg}$ of ${ }^{32} \mathrm{Th}$ and $4810 \mathrm{~Bq} / \mathrm{kg}$ of ${ }^{40} \mathrm{~K}$ produce the same gamma ray dose rate (Beretka and Mathew, 1985, and Tufail et al., 1992)

$$
\mathrm{Ra}_{\mathrm{eq}}=\mathrm{A}_{\mathrm{U}}+1.43 \mathrm{~A}_{\mathrm{Th}}+0.077 \mathrm{~A}_{\mathrm{K}}
$$

where $A_{U}, A_{T h}$ and $A_{K}$ are the specific activities of ${ }^{238} \mathrm{U},{ }^{232} \mathrm{Th}$ and ${ }^{40} \mathrm{~K}$ in $\mathrm{Bq} / \mathrm{kg}$. $\mathrm{Ra}_{\mathrm{eq}}$ was estimated for the collected rocks are given in Table 2. The values of $\mathrm{Ra}_{\mathrm{eq}}$ varied from 188.2 to 224.7 with average value $205.68 \mathrm{~Bq} / \mathrm{kg}$ for monzogranites, varied from 260.3 to $435.8 \mathrm{~Bq} / \mathrm{kg}$ with average $320.4 \mathrm{~Bq} / \mathrm{kg}$ for syenogranites and from 203.9 to 299 with average value $235.6 \mathrm{~Bq} / \mathrm{kg}$ for alkali feldspar granites. The obtained results for the studied younger granites are lower than the acceptable world value (370 Bq/kg), Table (2) and Figure 8.

\section{Gamma activity index, $\mathbf{I}_{\gamma}$}

The restriction on building materials for gamma radiation is based on a dose range of $0.3-1 \mathrm{mSv} / \mathrm{y}$ (NEA-OECD, 1979, Tzortziset al., 2003). In order to examine whether a building material meets these limits of dose criteria, the gamma activity concentration index $\mathrm{I}_{\gamma}$ was calculated from the following equation (Tzortziset al., 2003):

$$
\mathrm{I}_{\gamma}=\frac{A_{U}}{300}+\frac{A_{T h}}{200}+\frac{A_{K}}{3000}
$$

$\mathrm{A}_{\mathrm{U}}, \mathrm{A}_{\mathrm{Th}}$ and $\mathrm{A}_{\mathrm{K}}$ are the concentrations of ${ }^{238} \mathrm{U},{ }^{232} \mathrm{Th}$ and ${ }^{40} \mathrm{~K}$, respectively, in $\mathrm{Bq} / \mathrm{kg}$. The above equation based on the fact that, radionuclides contribute to the external irradiation according to the ratios of their specific exposure rate constants, i.e., ${ }^{40} \mathrm{~K}:{ }^{238} \mathrm{U}:{ }^{232} \mathrm{Th}=1: 10: 15$. This method uses the sum of three specific activity quotients as an index of gamma irradiation with denominators chosen to reflect the specific exposure rate and yield a sum equal to unity. For the activity concentration index, $\mathrm{I}_{\gamma}$ $\leq 2$ corresponds to a dose criterion of $0.3 \mathrm{mSv} \mathrm{y}^{-1}$, while $\mathrm{I}_{\gamma} \leq 6$ corresponds to $1 \mathrm{mSv} \mathrm{y}^{-1}$ in the report of the European Commission in 1999, as mentioned by Tzortziset al., (2003) and Anjos et al., (2005).

Thus, the activity concentration index should be used only as a screening tool for identifying materials which might be of concern to be used as construction or covering materials. According to this dose criterion, materials with $\mathrm{I}_{\gamma} \geq 6$ should be avoided (Ravisankar et al., 2012), whereas these values correspond to dose rates higher than $1 \mathrm{mSv} / \mathrm{y}(\mathrm{EC}, 1999)$, which is the highest value of dose rate in air recommended for population (UNSCEAR,1988, 1993a, 1993b,2000).

Values of $\mathrm{I}_{\gamma}$ ranged from 0.37 to 0.87 with average value 0.79 for monzogranites, from 0.99 to 1.6 with average 1.21 for syenogranites and from 0.82 to 1.15 with average value 0.93 for alkali feldspar granites. The average values of gamma activity index of the studied monzogranites and alkali feldspar granites rock types are lower than the acceptable value (2), Table (2) and Figure 8.

\section{Alpha activity index, $\mathbf{I}_{\alpha}$}

As radon progeny decay, they emit radioactive alpha particles and attach to aerosols, dust and other particles in the air. As we inhale, radon progeny are deposited on the cells lining the airways where the alpha particles can damage DNA and potentially cause lung cancer.

Several alpha indices have been proposed to assess the exposure level due to radon inhalation originating from building materials (European Commission (EC), 1999) (Krieger, 1981). Therefore the excess alpha radiation due to radon inhalation originating from building materials is estimated through the alpha index $\left(I_{\alpha}\right)$, which is defined as follows: (Elham Bavarnegin et al, 2013; Righi and Luigi Bruzzi, 2006, Zubair et al., 2013).

$$
\mathrm{I}_{\alpha}=\frac{A_{U}}{200} \leq 1
$$


El Afandy A. H. and El Shayib G. B.

$A_{U}$ is the activity concentration of ${ }^{238} \mathrm{U}$. The recommended exemption and upper level of ${ }^{238} \mathrm{U}$ activity concentrations in building materials are 100 and $200 \mathrm{~Bq} / \mathrm{kg}$, respectively, as suggested by ICRP, 1994. Thus, the recommended maximum concentration of ${ }^{238} \mathrm{U}$ is $200 \mathrm{~Bq} / \mathrm{kg}$, which gives $I_{\alpha}=$ 1 . When the ${ }^{226} \mathrm{Ra}$ activity concentration of any building material exceeds this maximum value $(200$ $\mathrm{Bq} / \mathrm{kg}$ ), it is possible that radon exhalation from such material could cause the indoor radon concentration to exceed $200 \mathrm{~Bq} / \mathrm{kg}$.

Values of $I_{\alpha}$ ranged from 0.11 to 0.16 with average value 0.13 for monzogranites, from 0.23 to 0.56 with average 0.35 for syenogranitesand from 0.09 to 0.17 with average value 0.13 foralkali feldspar granites. We can notice that the values of alpha activity index are lower than the acceptable value. It can, therefore, be said that radon inhalation from buildings constructed with these materials is low and we can used these rocks for building constructions, Table (2) and Figure 8..

\section{Hazard indices $\left(\mathrm{H}_{\mathrm{ex}}\right.$ and $\left.\mathrm{H}_{\mathrm{in}}\right)$}

\section{External hazard index, $H_{e x}$}

The external hazard index $\left(\mathrm{H}_{\mathrm{ex}}\right)$ is used to measure the external hazard due to the emitted gamma radiation. It was calculated by the equation from (Beretka and Mathew, 1985; Orgun et al., 2007; S. Fares, et al., 2012):

$$
\mathrm{H}_{\mathrm{ex}}=\mathrm{A}_{\mathrm{U}} / 370+\mathrm{A}_{\mathrm{Th}} / 259+\mathrm{A}_{\mathrm{K}} / 4810 \leq 1
$$

Where $H_{\text {ex }}$ is the external hazard index and $A_{U}, A_{T h}$ and $A_{K}$ are the specific activities of ${ }^{238} U,{ }^{232} T h$ and ${ }^{40} \mathrm{~K}$, in $\mathrm{Bq} / \mathrm{kg}$, respectively. The external hazard index is obtained from $\mathrm{Ra}_{\mathrm{eq}}$ expression through the supposition that its maximum value allowed (equal to unity) corresponds to the upper limit of $\mathrm{Ra}_{\mathrm{eq}}$ $(370 \mathrm{~Bq} / \mathrm{kg}$ ). The value of this index must be less than unity for the radiation risk from building material to be negligible (Grasety et al., 1984 and Hayumbu et al., 1995). For the maximum value of $\mathrm{H}_{\mathrm{ex}}$ to be less than unity, the maximum value of $\mathrm{Ra}_{\mathrm{eq}}$ must be less than $370 \mathrm{Bqkg}^{-1}$.

Values of $\mathrm{H}_{\mathrm{ex}}$ ranged from 0.51-0.61 with average value 0.56 for monzogranites, 0.7-1.18 with average value 0.87 for syenogranites and from 0.55 to 0.81 with average value 0.64 for alkali feldspar granites. The results of external hazard index reveal that its values for the studied granitic rock samples are lower than the acceptable value. So, no radiation risk from these rocks can occurred, Table (2) and Figure 8.

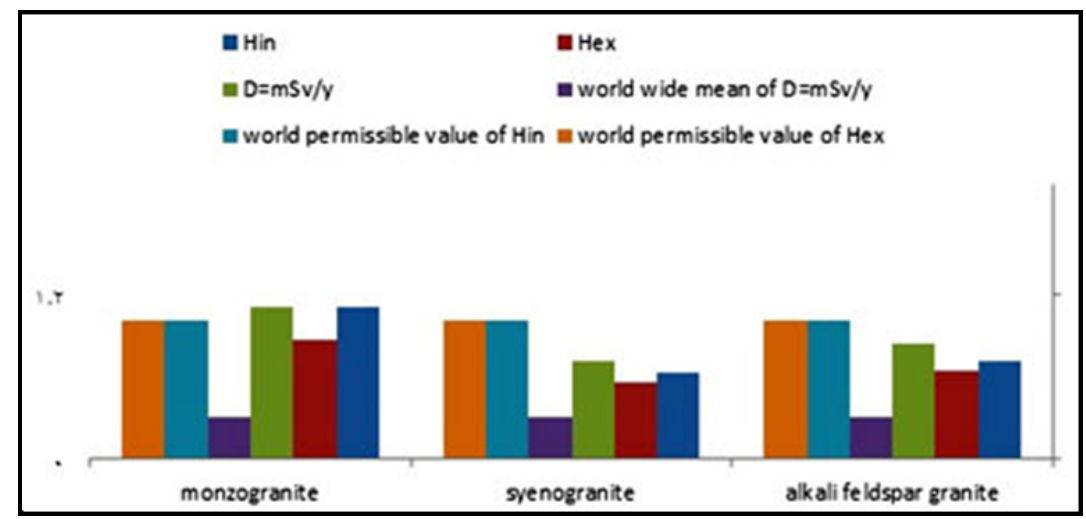

Fig. 8: Dose rate (DR), external hazard index (Hex), internal hazard index (Hin) of the studied rocks with their corresponding worldwide mean

\section{Internal hazard index, $\mathrm{H}_{\text {in }}$}

The internal hazard index $\left(\mathrm{H}_{\text {in }}\right)$ is used to control the internal exposure to ${ }^{222} \mathrm{Rn}$ and its radioactive progeny. It is given by the following equation (Beretka and Mathew, 1985; Orgun et al., 2007; S. Fares, et al., 2012):

$$
\mathrm{H}_{\text {in }}=\mathrm{A}_{\mathrm{U}} / 185+\mathrm{A}_{\mathrm{Th}} / 259 \mathrm{~A}_{\mathrm{K}} / 4810 \leq 1
$$

$\mathrm{A}_{\mathrm{U}}, \mathrm{A}_{\mathrm{Th}}$ and $\mathrm{A}_{\mathrm{K}}$ are the concentrations of ${ }^{238} \mathrm{U},{ }^{232} \mathrm{Th}$ and ${ }^{40} \mathrm{~K}$, respectively, in $\mathrm{Bq} \mathrm{kg}^{-1}$. If the maximum concentration of uranium in samples under study is half that of the normal acceptable limit, then the value of $\mathrm{H}_{\text {in }}$ will be less than 1 (Beretka and Mathew, 1985). For the safe use of a material in the construction of dwelling, $\mathrm{H}_{\text {in }}$ should be less than unity (Beretka and Mathew, 1985). Values of $\mathrm{H}_{\text {in }}$ ranged from 0.57-0.68 with average value 0.63 for monzogranites, $0.83-1.5$ with average value 1.1 for syenogranites and from 0.6 to 0.9 with average value 0.71 for alkali feldspar granites. The results of 
internal hazard index reveal that its values for the studied monzgranite and alkali feldspare granitic rocks are lower than the acceptable value.So,no radiation risk from these rocks can occurred, but the syenogranitic rock samples are slightly higher than the acceptable value, So, the radiation risk from the syenogranitc samples are hazard to the respiratory organs, therefore it can't used as a safety materials in the construction of dwelling, Table (2) and Figure 9.

\section{External dose from naturally occurring radionuclides}

\section{External absorbed dose rate in outdoor air, $D_{\text {out }}$}

The external absorbed dose rates $\mathrm{D}$, in outdoor air at $1 \mathrm{~m}$ above the ground level, to the population can be calculated from activities of terrestrial radionuclides according to the following formula (Saito and Jacob, 1995, Saito et al., 1998 and Kohshi et al., 2001):

$$
\mathrm{D}=\mathrm{A}_{\mathrm{Ei}} \times \mathrm{C}_{\mathrm{F}}
$$

Where $\mathrm{A}_{\mathrm{Ei}}$ is the activity concentration $\left(\mathrm{Bq} \mathrm{kg}{ }^{-1}\right.$ ), and $\mathrm{C}_{\mathrm{F}}$ is the dose conversion factor (absorbed dose rate in air per unit activity per unit mass in units of $\mathrm{nGy} \mathrm{h}^{-1}$ per $\mathrm{Bq} \mathrm{kg}^{-1}$ ). Dose conversion factors have been extensively calculated during the last 40 years by many researchers. In the present work, the considered dose rate conversion factors for ${ }^{238} \mathrm{U},{ }^{232} \mathrm{Th}$ and ${ }^{40} \mathrm{~K}$ are those determined by Quindos et al., (2004)where $\mathrm{C}_{\mathrm{U}}=0.4551, \mathrm{C}_{\mathrm{Th}}=0.5835$ and $\mathrm{C}_{\mathrm{K}}=0.0429$.

Values of $\mathrm{D}_{\text {out }}$ ranged from 80.8-108.2 with average value 98.8 for monzogranites, 125.200 .8 with average value 151.9 for syenogranites and from 103.3 to 143.4 with average value 116.6 for alkali feldspar granites.

\section{External absorbed dose rate in indoor air, $D_{\text {in }}$}

Since samples under investigation are extensively used as construction material of dwelling, so it is important to estimate its contribution to indoor exposure. Considering the indoor contribution is 1.4 times higher than outdoor dose (UNSCEAR, 2000), the indoor dose rate was calculated as well:

$$
\mathrm{D}_{\text {in }}=\mathrm{D}_{\text {out }} \times 1.4
$$

Values of $D_{\text {in }}$ ranged from ranged from 171.1-151.5 with average value 138.3 for monzogranites, 175-281.1 with average value 212.7 for syenogranites and from 144.6 to 200.8 with average value 163.26 for alkali feldspar granites.

We can observe that the average values of outdoor dose rates $\left(D_{\text {out }}\right)$ and indoor dose rates $\left(D_{\text {in }}\right)$ for the rock samples under investigation are higher than the acceptable world values and the acceptable Egypt values reported in UNSCEAR (2000) report (table 2).

\section{Annual effective dose, AEDE}

Annual estimated average effective dose equivalent (AEDE) received by an individual was calculated using a conversion factor of $0.7 \mathrm{~Sv} / \mathrm{Gy}$, which was used to convert the absorbed rate to the human (adults) effective dose equivalent with an outdoor occupancy of $20 \%$ and $80 \%$ for indoors (UNSCEAR, 1993b). The annual effective dose is determined using the following equations:

$$
\begin{gathered}
\mathrm{AEDE}\left(\text { outdoor) }=\mathrm{D}_{\text {out }} \mathrm{nGy} / \mathrm{h} \times 8760 \mathrm{~h} \times 0.7 \mathrm{~Sv} / \mathrm{Gy} \times 0.2\right. \\
\mathrm{AEDE}(\text { indoor })=\mathrm{D}_{\text {in }} \mathrm{nGy} / \mathrm{h} \times 8760 \mathrm{~h} \times 0.7 \mathrm{~Sv} / \mathrm{Gy} \times 0.8
\end{gathered}
$$

Results which recorded in table (2) indicated that monzogranitic rocks characterized by annual outdoor effective dose ranged from 0.11 to 0.13 with average value $0.2 \mathrm{mSv}$. and an annual indoor effective dose ranged from 0.62 to 0.74 with average value $0.68 \mathrm{mSv}$. With respect to syenogranites, and alkali feldspar granites, their values ranged from 0.15 to 0.25 with average value $0.19 \mathrm{mSv}$ and from 0.86 to 1.38 with average value $1 \mathrm{mSv}$ and from $0.13-0.18$ with average 0.14 and from 0.71 to 1.09 with average 0.8 for annual outdoor effective dose and annual indoor effective dose, respectively.

Using the above equations, the annual effective doses for infants and children can also calculate taken into account the numerical values, 0.8 and, 0.9 of conversion factor for children and infants, respectively as reported in UNSCEAR (2000).

The results obtained from table (2) implied that the average values of the outdoor and the indoor annual effective dose equivalent for the studied rock types are higher than the world value. 
El Afandy A. H. and El Shayib G. B.

Consequently the total annual effective dose equivalent for monzogranites $(0.8 \mathrm{mSv})$, alkali feldspar granites $(0.94 \mathrm{mSv})$ and syenogranites $(1.19)$ is much higher than the total world value $(0.48 \mathrm{mSv})$.

\section{Annual gonadal dose equivalent, AGDE}

The gonads, the active bone marrow and the bone surface cells are considered as organs of interest by UNSCEAR (1988). Therefore, the annual gonadal dose equivalent (AGDE) due to the specific activities of ${ }^{238} \mathrm{U},{ }^{232} \mathrm{Th}$, and ${ }^{40} \mathrm{~K}$ was calculated using the following formula (Mamont-Ciesla et al., 1982; Zaidiet al., 1999; Arafa, 2004; Chandrasekaran et al., 2014):

$$
\mathrm{AGDE}=\left(3.09 \times \mathrm{A}_{\mathrm{U}}+4.18 \times \mathrm{A}_{\mathrm{Th}}+0.314 \times \mathrm{A}_{\mathrm{K}}\right) \times 10^{-3}
$$

$\mathrm{A}_{\mathrm{U}}, \mathrm{A}_{\mathrm{Th}}$ and $\mathrm{A}_{\mathrm{K}}$ are the activity concentrations of ${ }^{238} \mathrm{U},{ }^{232} \mathrm{Th}$ and ${ }^{40} \mathrm{~K}$, receptively in $\mathrm{Bq} / \mathrm{kg}$.

Values of AGDE ranged from 0.65 to 0.78 with average value $0.71 \mathrm{mSv}$ for monzogranites, from 0.9 to 1.43 with average $1.1 \mathrm{mSv}$ for syenogranites and from 0.75 to 1.031 with average value 0.84 $\mathrm{mSv}$ for alkali feldspar granites. The results imply that values of annual gonadal dose equivalent for the study rocks are higher than the world value $(0.3 \mathrm{mSv})$ reported by Zaidi et al., (1999).

\section{Excess lifetime cancer risk (ELCR)}

This deals with the probability of developing over a lifetime at a given exposure level. It is presented as a value representing the number of extra cancers expected in a given number of people on exposure to a carcinogen at a given dose. Excess lifetime cancer risk (ELCR) is given as (Taskin et al., 2009; Shams et al., 2013; Ajibode et al., 2013; Avwiri, et al. 2012)

$$
\mathrm{ELCR}=\mathrm{AEDE} \times \mathrm{DL} \times \mathrm{RF}
$$

Where, AEDR is the Annual Equivalent Dose Equivalent, DL is average Duration of Life (estimated to be 70 years), and RF is the Risk Factor $\left(\mathrm{Sv}^{-1}\right)$, i.e. fatal cancer risk per Sievert. For stochastic effects, ICRP (1990) uses RF as 0.05 for the public (Taskin et al., 2009).

Values of excess lifetime cancer risk ranged from $2.2 \times 10^{-3}$ to $2.6 \times 10^{-3}$ with average value $2.4 \times 10^{-}$ ${ }^{3} \mathrm{~m}$ from $3 \times 10^{-3}$ to $4.8 \times 10^{-3}$ with average $3.7 \times 10^{-3}$ and from $2.5 \times 10^{-3}$ to $3.5 \times 10^{-3}$ with average value 2.8. $\times 10^{-3}$ for monzogranites, syenogranites and alkali feldspar granites respectively.

The average values of excess lifetime cancer risk are higher than the world value $\left(0.29 \times 10^{-3}\right)$ which reported in UNSCEAR (2000) report. This implies that the chances of having cancer by the workers who works in the study region are significant. In addition, these values are an important alert for the companies to avoid the use of these rocks as raw building materials.

\section{SUMMARY AND CONCLUSIONS}

The Abu Marw area is mainly covered by Late Proterozoic igneous and metamorphic rocks. These basement rocks are nononconformably overlain by Cretaceous Nubian sandstone in the western and northern parts of the study area. The field geological investigation of the different rock units, with references to their mode of occurrence, mutual relationships, petrographical study and regional structure resulted that the investigated area was covered from the oldest to the youngest rocks by metagabbros, metavolcanics, Older granites (tonalities and granodiorites) and Younger granites (monzogranites, syenogranites and Alkali-feldspar granites).

This study concludes that the younger granitic rocks at Abu Marw area have low uranium, thorium and radium contents, where the average contentes of uranium are $1.14 \mathrm{ppm}, 5.7 \mathrm{ppm}$ and $2.1 \mathrm{ppm}$ for monzogranite, syenogranites and alkali feldspar granites and the average values of thorium contents in these rocks are $15.2 \mathrm{ppm}, 22.5 \mathrm{ppm}$ and $13.8 \mathrm{ppm}$ respectively. The excess values of uranium and thorium contents in syenogranites are due to the more contents of uranium and thorium bearing minerals in these rocks. The values of The radium equivalent activity (Raeq), gamma activity index $(\mathrm{I} \gamma)$, alpha activity index (I $\alpha)$, external hazard index (Hex), internal hazard index (Hin), external absorbed dose rate in outdoor $\left(\mathrm{D}_{\text {out }}\right)$ and indoor $\left(\mathrm{D}_{\mathrm{in}}\right)$, annual effective dose (AEDE), annual gondal dose equivalent (AGDE) and excess lifetime cancar risk (ELCR) are lower than the public permissible values in themonzogranites and alkali feldspar granites rocks and they are within the safety range for the public and workers. So, the monzogranites, and alkali feldspar rocks in the studied area are safety for the building and ornamental materials. 
Table 2: Exposure rate (ER), dose rate (DR), radium equivalent activity (Raeq), external hazard index (Hex), internal hazard index (Hin) and radioactivity level index (I y) of the studied rocks

\begin{tabular}{|c|c|c|c|c|c|c|c|c|c|c|c|}
\hline \multirow{2}{*}{ Rock type } & \multirow{2}{*}{$\mathrm{Ra}_{\mathrm{eq}}(\mathrm{Bq} / \mathrm{kg})$} & \multicolumn{2}{|c|}{ Activity indices } & \multicolumn{2}{|c|}{ Hazard indices } & \multicolumn{2}{|c|}{ External absorbed dose } & \multicolumn{2}{|c|}{ AEDE } & \multirow{2}{*}{ AGDE mSv } & \multirow{2}{*}{$\mathrm{E} \mathrm{LCR} \times 10^{-3}$} \\
\hline & & $\mathrm{I}_{\gamma}$ & $\mathrm{I}_{\alpha}$ & $\mathrm{H}_{\mathrm{ex}}$ & $\mathrm{H}_{\text {in }}$ & $\mathrm{D}_{\text {out }}$ & $\mathrm{D}_{\text {in }}$ & outdoor & indoor & & \\
\hline Alkali Feldspar & $\begin{array}{c}203.9-299 \\
(235.6) \\
\end{array}$ & $\begin{array}{c}0.82-1.15 \\
(0.93)\end{array}$ & $\begin{array}{c}0.09-0.17 \\
(0.13)\end{array}$ & \begin{tabular}{|c|}
$0.55-0.81$ \\
$(0.64)$
\end{tabular} & $\begin{array}{c}0.6-0.9 \\
(0.71) \\
\end{array}$ & $\begin{array}{c}103.3-143.4 \\
(116.6)\end{array}$ & $\begin{array}{c}144.6-200.8 \\
(163.26)\end{array}$ & $\begin{array}{c}0.13-0.18 \\
(0.14)\end{array}$ & \begin{tabular}{|c|}
$0.71-0.99$ \\
$(0.8)$ \\
\end{tabular} & $\begin{array}{c}0.75-1.03 \\
(0.84) \\
\end{array}$ & $\begin{array}{c}2.5-3.5 \\
(2.8)\end{array}$ \\
\hline synogranite & $\begin{array}{c}260.3-435.8 \\
(320.4)\end{array}$ & $\begin{array}{c}0.995-1.6 \\
(1.21)\end{array}$ & $\begin{array}{c}0.23-0.59 \\
(0.35)\end{array}$ & $\begin{array}{c}0.7-1.18 \\
(0.87)\end{array}$ & $\begin{array}{c}0.83-1.5 \\
(1.1)\end{array}$ & $\begin{array}{c}125-200.8 \\
(151.9)\end{array}$ & $\begin{array}{c}175-281.1 \\
(212.7)\end{array}$ & $\begin{array}{c}0.15-0.25 \\
(0.19)\end{array}$ & $\begin{array}{c}0.86-1.38 \\
(1)\end{array}$ & $\begin{array}{c}0.9-1.43 \\
(1.1)\end{array}$ & $\begin{array}{l}3-4.8 \\
(3.7)\end{array}$ \\
\hline Monzogranite & $\begin{array}{c}188.2-224.7 \\
(205.68)\end{array}$ & $\begin{array}{c}0.73-0.87 \\
(0.79)\end{array}$ & $\begin{array}{c}0.11-0.16 \\
(0.13)\end{array}$ & $\begin{array}{c}0.51-0.61 \\
(0.56)\end{array}$ & $\begin{array}{c}0.57-0.68 \\
(0.63)\end{array}$ & $\begin{array}{c}90.8-108.2 \\
(98.8)\end{array}$ & $\begin{array}{c}127.1-151.5 \\
(138.3)\end{array}$ & $\begin{array}{c}0.11-0.13 \\
(0.12)\end{array}$ & $\begin{array}{c}0.62-0.74 \\
(0.68)\end{array}$ & $\begin{array}{c}0.65-0.78 \\
(0.71)\end{array}$ & $\begin{array}{c}2.2-2.6 \\
(2.4)\end{array}$ \\
\hline World value & 370 & $\leq 2$ & $\leq 1$ & $\leq 1$ & $\leq 1$ & 59 & 84 & 0. & 48 & 0.3 & 0.29 \\
\hline
\end{tabular}


El Afandy A. H. and El Shayib G. B.

\section{REFERENCES}

Abbady, A.G. E., Uosifand, M. A. M., and El-Taher, A., (2005): Natural radioactivity and dose assessment for phosphate rocks from Wadi El-Mashash and El-Mahamid Mines, Egypt. J. Environ. Radioactivity 84(1):65-78 .

Abdel Halim E.S., (2016): Evaluation of natural radioactivity and excess lifetime cancer risk due to gamma dose rates from Egyptian black sand and its components. J. Physical Sci. and Environ. Studies. 2(2): 30-37.

Ajibode, M. O., Avwiri, G. O and Agbalagba, E. O. (2013): Evaluation of radiation hazard indices in an oil mineral lease (oil block) in Delta State, Nigeria. International J. Engineering and Applied Sci., 4, No. 2. اين رقم الصفحات

Al-Jundi, J., (2002): Population doses from terrestrial gamma exposure in areas near to old phosphatemine, Russaifa, Jordan. Radiat. Arabian J. Geosci., Meas. 35, 23-28.

Anjos, A. M., Veiga, R., Soares, T., Santos, A. M. A., Aguiar, J. G., Frascá, M. H. B. O., Brage, J. A. P., Uzêda, D., Mangia, L., Facure, A., Mosquera, B., Carvalho, C. and Gomes, P. R.S. (2005): Natural radionuclide distribution in Brazilian commercial granites. Radiation measurements, 39, 245-253.

Arafa, W. (2004): Specific activity and hazards of granites samples collected from the Eastern Desert of Egypt. J. Environ.1 radioactivity 75, 315-327.

Avwiri, G.O., Osimobi, J.C and Agbalagba, E.O. (2012): Evaluation of Radiation Hazard Indices and Excess Lifetime Cancer Risk Due to Natural Radioactivity in soil profile of Udi and Ezeagu Local Government Areas of Enugu State, Nigeria. Comprehensive J. Environ. and Earth Sci., 1(1), 1-10.

Beretka, J., and Mathew, P.J. (1985): Natural radioactivity of Australian building materials, industrial wastes and by-products. Health Phys. 48, 87-95.

Cuney, M.; Le fort, P., and Wang, Z.X. (1984): Uranium and Thorium Geochemistry and Mineralogy in the Manasluleucogranite (Nepal, Himalaya): Geology of Granites and Their Metallogenetic Relations (Proc. Symposium), Nanjing, 1982, Univ. Sci., Ed., 853-873.

Chandrasekaran A., Ravisankar R., Senthilkumar G., Thillaivelavan K., Dhinakaran B., Vijayagopal P., Bramha S.N., and Venkatraman B. (2014): Spatial distribution and lifetime cancer risk due to gamma radioactivity in Yelagiri Hills, Tamilnadu, India. Egypt. J. Basic and Appl. Sci., I, 38- 48.

EC. (1999): European Commission Report on "Radiological Protection Principles concerning the Natural Radioactivity of Building Materials". Radiation protection, 112.

El Afandy, A. H. (1994): Geology, petrology and radioactivity of the Basement rocks in Abu Marw SED- Egypt, Ph. D. Fac. Sci, Assiut Univ., Aswan Branch, 289P.

El Afandy, A. H., El Kammar, A. A., Abdel Gawad, A. E., and Rizk, T. N. (2018): Distribution of radionuclides in uraniferous two mica granites and their environmental inpact at El Sela shear zone, Southern Eastern Desert, Egypt., Nuclear Sciences Scientific J., 7, 135-149.

El Aassy, I. E., Afaf, A., Nada, B. N., El Galy, M.M., El Feky, M. G., Abd El., Maksoud, T. M., Talaat, Sh. M., and Ibrahim, E. M. (2012): Behavior and environmental impacts of radionuclides during the hydrometallurgy of calcareous and argillaceous rocks, southwestern Sinai, Egypt. Nuclear Materials Authority, Egypt, Faculty of Women for Arts, Science and Education, Egypt.

El Galy, A. M., El Mezayn, S., El Mowafy A. A., and Mohamed M. S. (2008): Distribution and environmental impacts of some Radionuclides in sedimentary rocks at Wadi Naseib area, southwest Sinai, Egypt, J. Environ. Radioactivity, 99, 1075-1082.

Elham Bavarnegin, Masoud Vahabi Moghaddam, and Nasrin Fathabadi (2013): Natural radionuclide and radiological assessment of building materials in high background radiation areas of Ramsar, Iran. J Med Phys. 2013 Apr-Jun; 38(2): 93-97.

Fares S., Ashour A., El-Ashry M., and Abd El-Rahman, M. (2012): Gamma radiation hazards and risks associated with wastes from granite rock cutting and polishing industries in Egypt. Ядернатарадіаційнабезпека 1 (53).УДК 539.16:553.521.

Friedrich, M.H.; Cuney, M., and Cregu, G. (1989): Uranium Enrichment Processes in Peraluminous Magmatism. Inter. Atomic Energy Agency, (IAEA)-TC-571/2.11-35.

Grasety, R. I., Carson, J.M., Charbonneau, B. W. andHolman, P. B. (1984): Natural background radiation in Canada. Geol. Surv. Can. Bull 360.

Hamby, D. M., and Tynybekov, A. K. (2000): Uranium, thorium and potassium in soils along the shore of lake IssyK-Kyol in the Kyrghyz Republic. Environ. Monit. Assess. 73, 101-108. 
Hamidalddin,S.H.Q. (2012):Study of Natural Radionuclides of some igneous rocks in Arabian Shield (South of Al- Madinah Al Munawarah), Saudi Arabia, J. Am. Sci. 2012; 8(12), 1524-1529.

Harb, S., El-Kamel, A. H., Abd El-Mageed, A. I., Abbady, A., \& Negm, H. (2008): Natural radioactivity measurements in soil. J. Radiation Res. and Applied Sci., 7 (2014) 292-304.

Hayumbu, P., Zaman, M. B., Lubaba, N. C. H., Munsanje, S. S. and Nuleya, D. (1995): Natural radioactivity in Zambian building materials collected from Lusaka. J. Radio analytical and Nuclear Chem., 199, 229-238.

ICRP. (1990): Recommendations of the Inte. Commission on Radiological Protection, 21(1-3), 60.

ICRP. (1994): Protection against radon-222 at home and at work. ICRP Publication 65, 23(2). Pergamon Press, Oxford.

International Atomic Energy Agency, (IAEA). (1996): Internal Basic Safety Standards for Protection against Ionizing Radiation and for the Safety of Radiation Sources. Safety Series No.115

International Atomic Energy, Agency (IAEA).(1989): Measurement of radionuclides in food and the environment, a guidebook, Technical Reports Series No. 229, Vienna.

International Atomic Energy Agency, (IAEA). (1979): Gamma-ray Surveys in uranium xploration.Technical Reports Series No. 186, Vienna, 89 p.

International Commission on Radiation Units and Measurements, (ICRU).(1980): .Radiation Quantities and Units.Report 33, Washington, DC.J. Environ. Radioact.73, 233245.

Kohshi, C., Takao, I. And Hideo, S. (2001): Terrestrial gamma radiation in Koshi prefecture, Japan. Journal of Health Science, 47 (4), 362-372.

Krieger, R. (1981): Radioactivity of construction materials. Betonwerk Fertigteil-Techn.47, 468- 473.

Malczewski, D.; Taper, L., and Dorda, J. (2004): Assessment of natural and anthropogenic radioactivity levels in rocks and soils in the environs of Swieradow Zdroj in Sudetes, Poland by in situ gamma-ray spectrometry. J. Environ. Radioact. 73, 233e245.

Mamont-Ciesla K, Gwiazdowski B, Biernacka M, Zak A. (1982): Radioactivity of building materials in Poland. In: Vohra G, Pillai KC, Sadavisan S, editors. Natural radiation environment. New York: Halsted Press; 551 p.

Matolin, M. (1991): Construction and Use of Spectrometric Calibration Pads Laboratory -ray spectrometry, NMA, Egypt. A Report to the Government of the Arab Republic of Egypt. Project EGY/4/030-03.IAEA.

Moghazy, N.M. (2016): Petrography, Gamma radiation measurements and dose rate, Northeastern Um Ara area, South Eastern Desert, Egypt. Nuclear Sciences Sci. J., 5, 91-108.

Nada, A. (2003): Evaluation of natural radionuclides at Um- Greifat area, eastern desert of Egypt. Appl. Radiation and Isotopes, 58,275-280.

Nagdya, M.I. (2003): Radioactive disequilibrium in the different rock types in Wadi Wizr, the Eastern Desert of Egypt. Applied Radiation and Isotopes, 58(3):385-392 .

Nuclear Energy Agency, NEA-OECD., (1979): Exposure to Radiation from Natural Radioactivity in Building Materials. Report by NEA Group of Experts. OECD, Paris.

Orgun,Y., Altinsoy N., Sahin S. Y., Gungor Y., Gultekin A. H., Karaham G., and Karaak Z., (2007): Natural and anthropogenic radionuclides in rocks and beach sands from Ezineregion (canakkale), Western Anatolia, Turkey. Applied Radiation and Isotopes, 739-747: 65.

Pal, D.C.; Mishra, B., and Bernhardt, H.J. (2007): Mineralogy and Geochemistry of Pegmatite-Hosted Sn-, Ta-Nb- and Zr-Hf-Bearing Minerals from the South eastern Part of the Bastar- Malkangiri Pegmatite Belt, Central India. Ore Geol. Rev., 30, 30-55. http://dx.doi.org/10.1016/j.oregeorev.2005.10.004.

Poty, B.; Cuney, M., and Friedrich, M. (1986): Uranium Deposits Spatially Related to Granites in the French Part of the Hercynian Orogeny, Vein Type Uranium Deposits. IAEA-TECDOC-361,

IAEA, Vienna, 215-246. Rameshbabu, P.V. (1999): Rare metal and rare Earth pegmatites of Central India. Sp. Issue on Rare metal and rare earth Pegmatites of India. Exploration and Res., 12, 7-52.

Quindos, L. S., Fernández, P.L., Ródenas, C., Gómez-Arozamena, J. and Arteche, J. (2004): Conversion factors for external gamma dose derived from natural radionuclides in soils. J. Environ Radioactivity, 71, 139- 145.

Rameshbabu, P. V. (1999): Rare metal and rare earth egmatites of Central India. Sp. Issue on Rare Metal and Rare Earth Pegmatites of India. Exploration and Resarch, 12, 7-52.

Rumyantsev, S. (1967): Industrial Radiology. Translated from the Russian by Semyonov, S. Mir Publishers, Moscow. Saito, K., and Jacob P., 1995. Gamma-ray fields in air due to sources in the ground. Radiat Prot Dosim. 58, 29-45:29. 
El Afandy A. H. and El Shayib G. B.

Ravisankar, R., Vanasundari, K., Chandrasekaran, A., Rajalakshmi, A., Suganya, M., Vijayagopal, P. and Meenakshisundaram, V. (2012): Measurement of Natural Radioactivity in Building Materials of Namakkal, Tamil Nadu, India Using Gamma-Ray Spectrometry, Applied Radiation and Isotopes, 70, 699-704.

Saito, K., and Jacob P. (1995): Gamma-ray fields in air due to sources in the ground. Rad. Prot. Dosim. 58, 29-45.

Saito, K.; Pattoussi, H., and Zankl, M. (1998): Calculation of the effective dose and its variation from environmental gamma ray sources. Health Phys., 74, 698-706.

Serena Righi and Luigi Bruzzi.(2006):Natural radioactivity and radon exhalation in building materials used in Italian dwellings. J. Environ.Radioactivity, 88 (2006) 158-170.

Shams I., Uosif M., and El saman R. (2013): Gamma radioactivity measurements in Nile River sediment samples. Turkish Journal of Engineering and Environmental Sciences.37: 109- 122.

Sroor, A., Abd El Halim, E.S., El-Shershaby, A., Walley el Dine, N., and Afifi, S. (2012): Evaluation of natural radionuclides for mica and quartz in Eastern Desert of Egypt using gamma ray spectrometry. J. Nuclear Physics and Atomic Energy, 13(2).

Taskin, H., Karavus, M., Ay, P., Topuzoglu, A., Hidiroglu, S. and Karahan, G. (2009):Radionuclide concentration in soil and lifetime cancer risk due to the gamma radioactivity in Kirklareli, Turkey. $\mathrm{J}$. environ. radioactivity, 100, 49-53.

Tufail, M.; Ahmed, M.; Shaib, S.; Safdar, A.; Mirza, N. M.; Ahmed, N.; Zafar, M. S., and Zafar, F.I. (1992): Investigation of gamma-ray activity and radiological hazards of the bricks fabricatedaroundLahor, Pakistan. Pak. J. Sci. Ind. Res. 34, 216-220.

Tzortzis, M., Tsertos, H., Christofides, S. and Christodoulides, G. (2003): Gamma radiation measurements and dose rates in commercially-used natural tiling rocks (granites).Journal of Environmental Radioactivity, 70, 223-235.

UNSCEAR. (2000): United Nations Scientific Committee on the effects of Atomic Radiation. Report to the General Assembly, with scientific annexes. Sources and Effects of Ionizing Radiation. United Nations sales publications No. E.00.IX.3 Volume I: Sources) and No. E.00.IX.4 (Volume II: Effects). United Nations, New York, 1220 pp.

UNSCEAR. (1993a): Sources and Effects of Ionizing Radiation. United Nations Scientific Committee on the Effects of Atomic Radiation, United Nations, New York.

UNSCEAR. (1993b): Exposure from natural sources of radiation. Forty-second session of United Nations Scientific Committee on the Effect of Atomic Radiation, Vienna 12-28 May.

UNSCEAR.(1988): Sources, Effects and Risks of Ionizing Radiation, Report to the General Assembly, United Nations, New York.

Walley El Dine, N., Sroor, A., Ali, Kh., Ibrahim, T., El-Shershaby, A., and El Taib, Z. (2012): Determination of specific activity of natural radioactivity for assessment of hazard radiation from the Egyptian row materials, J. Environ. Sci., 41(2), 457-467.

Zaidi, J. H., Arif, M., Ahmed, S., Fatima, I. And Qureshi, I. H. (1999): Determination of natural radioactivity in Building materials used in the Rawalpindi Islamabad area by $\gamma$-ray spectrometry and instrumental neutron activation analysis. Applied Radiation and Isotopes Journal 51, 559-564.

Zubair, M., Verma, D., Azam, A. and Roy, S. (2013): Natural radioactivity and radiological hazard assessment of soil using gamma-ray spectrometry. Radiat. Prot. Dosimetry, 155 (4): 467-473. 
Geology and distribution of radioelements

جيولوجية وتوزيع العناصر المشعه والتقييم البيئي لصخور الجرانيتات الحديثة في منطقه ابو مرو ، جنوب الصحراء الثرقيه مصر

عادل حسن اسماعيل الأفندي ، جيهان بكر الشايب

\section{الخلاصة}

تغطي منطقة أبو مرو بصخور البروتيوزوي المتأخر والمغطاه بصخور الحجر الرملي النوبي من الناحية الغربية والثمالية لمنطقة الدراسة ـ الدراسات والمشاهدات الحقلية للصخور الموجودة بمنطقة الدراسة وكذا الدراسات البتروجرافية بينت أن المنطقة مغطاه بصخور الجابرو المتحولة والصخور البركانية المنحولة وصخور النوناليت والجرانودايورايت

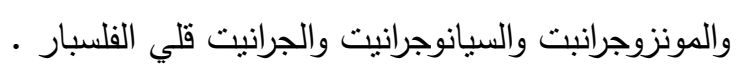

تتتاول هذه الدراسه توزيع النشاط الاشعاعي الطبيعي لصخور الجرانيتات المختلفهبمنطقة أبو مرو وتأثيرها علي البيئه المحيطه بها ، حيث نم حساب معدل التعرض ومعدل الجرعه الاشعاعيه ونشاط الراديوم ومؤشري الخطر الداخلي لألئي والخارجي ومؤشر المعدل الاشعاعي .

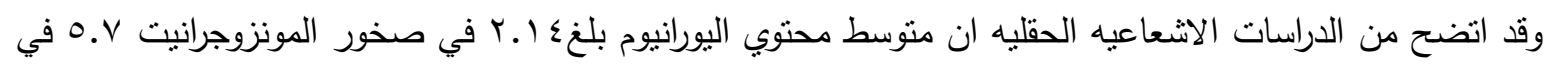

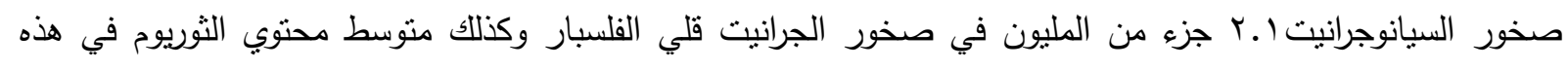

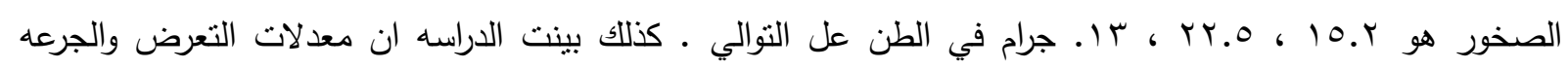

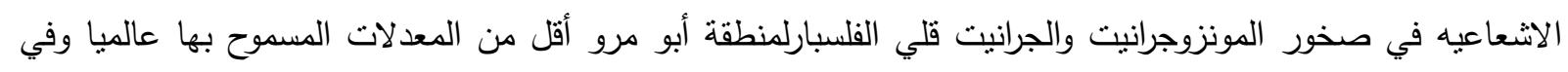

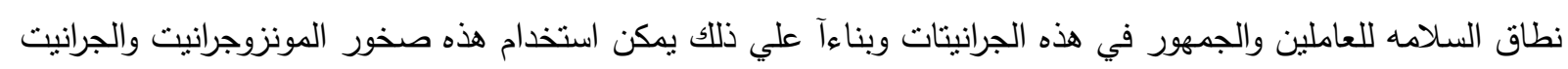
قلي الفلسبار في البناء وأحجار الزينة. 